Vol 1 No 11, November 2021

E-ISSN: 2775-6440 | P-ISSN: 2808-7208

Jurnal Homepage https://fusion.rifainstitute.com

\title{
KONTESTASI POLITIK PEREMPUAN DALAM DISKURSUS GENDER DAN EKONOMI POLITIK
}

\author{
Fajar Assidiq, Krisnaldo Triguswinri \\ Universitas Diponegoro, Indonesia \\ Email: Fassidiq3@gmail.com, Krisnaldo.triguswinri@gmail.com
}

\begin{abstract}
The impact of the implementation of Law Number 2 of 2011 concerning Political Parties Including Women's Representation of at least 30 percent (Affirmative Action) is considered to have an impact on the quantitative aspect, but on the qualitative aspect. This is because the implementation of this policy tends to be interpreted as administrative settlement by political parties participating in the election, until finally the fact emerges that the growth of political recruitment in the regions is increasing. The purpose of writing this research is to reveal the qualitative reality of the application of the 30 percent quota for women in electoral politics in the midst of the big wave of oligarchy in Indonesia. Therefore, it is difficult for female candidates who are not incumbent candidates, oligarchs or who represent oligarchs to be able to win political contests. In the end, their contestation is only limited to complement the sufferer. Therefore, to reach the wealth of data, this article uses a qualitative method which aims to describe social phenomena that are holistic in nature in a natural setting. The result of this study is that economic modality is the only determining factor in the contestation of women in electoral politics in Indonesia, in this case in Cilacap as one of the regional representations in Indonesia.
\end{abstract}

Keyword: Women's Political Contest; Oligarchy; Patronage and Clientelism.

\begin{abstract}
Abstrak
Dampak implementasi Undang-Undang Nomor 2 Tahun 2011 tentang Partai Politik Menyertakan Keterwakilan Perempuan Minimal 30 persen (Affirmative Action) dinilai berdampak pada aspek kuantitatif, namun pada aspek kualitatif. Hal ini terjadi karena penerapan kebijakan ini cenderung diartikan sebagai pelunasan administratif oleh partai politik (parpol) peserta pemilu, hingga akhirnya muncul kenyataan bahwa memang pertumbuhan rekrutmen politik di daerah meningkat. Tujuan dari penulisan penelitian ini adalah untuk membuka realita kualitatif penerapan kuota 30 persen perempuan dalam penyelenggaraan politik elektoral di tengah-tengah gelombang besar oligarki di Indonesia. Oleh karena itu, sulit rasanya bagi kandidat perempuan yang mereka bukan merupakan kandidat petahana, oligarki maupun yang merepresentasikan oligarki untuk dapat memenangkan kontestasi politik. Pada akhirnya, kontestasi mereka hanya sebatas pelengkap penderita. Oleh karena itu, untuk menjangkau kekayaan data tersebut, artikel ini menggunakan metode kualitatif yang
\end{abstract}


bertujuan untuk mendeskripsikan fenomena sosial yang bersifat holistik dalam natural setting. Hasil penelitian ini adalah modalitas ekonomi menjadi satusatunya faktor determinan dalam kontestasi perempuan dalam politik elektoral di Indonesia, dalam hal ini di Cilacap sebagai salah satu representasi wilayah di Indonesia.

Kata Kunci: Kontestasi Politik Perempuan; Oligarki; Patronase dan Klientelisme.

Diterima: 03-11-2021

Direvisi: 13-11-2021

Diterbitkan: 20-11-2021

\section{Pendahuluan}

Kuota 30 persen yang diwajibkan kepada partai politik (parpol) peserta pemilu sebagai konsekuensi penerapan Undang-Undang Nomor 2 Tahun 2011 Tentang Partai Politik Menyertakan Keterwakilan Perempuan Minimal 30 Persen di sisi lain berhasil menyerap calon legislatif (caleg) potensial, di sisi lain juga hanya sebatas dipatuhi sebagai peraturan yang bersifat formalitas. Dalam hal ini, parpol mau tidak mau harus mencalonkan caleg perempuan agar dapat mengikuti pemilihan umum (pemilu). Pada akhirnya, muncul caleg perempuan yang tidak kompeten, tidak representatif bahkan banyak yang menjadikannya sebagai "pajangan” belaka. Mereka terdaftar sebagai caleg namun teknisnya tidak melakukan kampanye sama sekali.

Pada kenyataanya, selain muncul fenomena caleg perempuan tersebut tidak sedikit muncul caleg perempuan yang kompeten, namun tidak mewakili kekuatan elit ekonomi-politik (oligarki). Pada akhirnya, biasanya mereka menjadi korban penerapan zip sistem dalam penentuan nomor urut (Marwah 2014). Oleh karena itu, caleg perempuan dengan nomor urut kecil sangat sedikit jumlahnya. Hal ini tentu semakin menghambat kontestasi perempuan dalam pemilu. Hal ini karena secara psikologis nomor urut cukup menentukan perilaku pemilih konstituen. Maka demikian, permasalahan kontestasi perempuan dalam dinamika politik elektoral di Indonesia jika dilihat lebih mendalam bukan sekedar permasalahan teknis yang bersifat kuantitatif (pemenuhan 30 persen lantas dicap sebagai pemilu yang representatif), namun jika dilihat secara kualitatif keterlibatan oligarki sangat berpengaruh.

Artinya, sekalipun terdapat caleg perempuan potensial, namun jika tidak mewakili oligarki kemungkinan besar kalah dalam kontestasi. Hal ini logis melihat arah perkembangan politik elektoral Indonesia yang mengarah kepada politik plutokrasi yang berujung pada candidate-centered politics (Muhtadi 2013), yang mana satu-satunya variabel yang paling dilihat dari latar belakang seorang kandidat adalah kekuatan ekonominya. Hal ini turut didukung sikap permisifnya konstituen terhadap kehadiran politik uang (Fitriyah 2015) serta melemahnya Party-ID (identitas kepartaian) (Muhtadi 2018).

Artikel ini mengambil lokus penulisan di Cilacap, yakni sebuah kabupaten yang memiliki struktur sosio-ekonomi lemah. Dalam hal ini, menurut pendekatan modernis yang diutarakan Lipset menyatakan bahwa munculnya fenomena politik uang di negara demokrasi dunia ketiga sangat dipengaruhi oleh rendahnya tingkat pendidikan dan 
ekonomi (Lipset 1959). Atas latar belakang struktur sosio-ekonomi tersebut pemilihan Cilacap sebagai lokus penulisan makalah ini menjadi korelatif.

Alasan berikutnya yang menjadikan Cilacap dipilih sebagai lokus penulisan ini karena Cilacap cukup mewakili permasalahan-permasalahan yang sudah dijelaskan pada paragraf-paragraf sebelumnya, yaitu meskipun kuota 30 persen perempuan telah terpenuhi secara kuantitatif dan administratif, namun kenyataannya jumlah caleg perempuan yang berhasil mendapatkan kursi parlemen hanya mereka yang merupakan caleg incumbent (petahana) dan caleg yang mewakili elit ekonomi-politik.

Kemenangan kandidat petahana wajar terjadi di Indonesia karena kandidat petahana memiliki keuntungan kepetahanaan (incumbency advantages) (Sukmajati 2015) dalam politik distributif (Stokes et al. 2014) yang dekat dengan pengadaan patronase sebagai alat mobilisasi massa (Sukmajati 2015). Meskipun secara sosiokultural, masyarakat Cilacap dikenal memiliki jiwa egalitarianisme, namun kenyataannya tetap terjadi hubungan yang bersifat seksis antar laki-laki dan perempuan (Marwah 2014). Terlebih di tengah-tengah arus kuat oligarki, maka dalam pertarungan politik elektoral hal yang paling signifikan menentukan kemenangan adalah kekuatan ekonomi (Rofieq and Nuryono 2017). Berdasarkan pada pemaparan tersebut maka penulisan artikel ini bertujuan untuk mendeskripsikan dan menjelaskan tentang kontestasi politik perempuan di Cilacap dalam diskursus gender dan ekonomi politik. Dari penulisan makalah ini diharapkan dapat memberikan sumbangsih pemikiran terhadap perkembangan ilmu politik dalam ruang lingkup gender dan politik, terutama dalam konteks dinamika politik elektoral di tingkat lokal yang masih belum banyak dikaji oleh kalangan akademisi ilmu politik lainnya.

\section{Metode Penelitian}

Metode penelitian yang akan digunakan dalam penulisan artikel ini adalah metode penelitian kualitatif. Pemilihan tersebut disesuaikan dengan tujuan penulisan, yakni mendeskripsikan dan menjelaskan tentang kontestasi politik perempuan di Cilacap dalam diskursus gender dan ekonomi politik. Dalam pengertian ini, penelitian kualitatif bertujuan untuk mendeskripsikan fenomena sosial yang bersifat holistik dalam natural setting. Itu, artinya peneliti tidak berusaha untuk memanipulasi situs (setting) penelitian ataupun melakukan intervensi terhadap aktivitas subjek penelitian dengan memberikan perlakuan tertentu (Idrus 2007). Penelitian ini berusaha memahami fenomena yang dirasakan subjek sebagaimana adanya. Dengan demikian, sifat penelitian ini lebih menekankan pada pemahaman tentang makna (verstehen).

\section{Hasil dan Pembahasan}

\section{Profil Cilacap: Sosio-Ekonomi, Sosio-Kultural dan Sosio-Politik}

Cilacap merupakan wilayah kabupaten yang terletak di Jawa Tengah dan sebagian wilayah lainnya, terutama di sebelah barat berbatasan langsung dengan Jawa Barat. Jika kondisi geografis tersebut dilihat lebih detail, maka Cilacap berbatasan 
dengan Kabupaten Banyumas, Jawa Tengah dan Kota Banjar Patroman, Jawa Barat. Sedangkan jika dilihat dari arah mata angin lainnya, maka di sebelah selatan berbatasan langsung dengan Samudera Hindia dengan Pulau Nusakambangan sebagai penanda alami teritorial dan di sebelah utara berbatasan langsung dengan Kabupaten Brebes.

Letaknya yang berada di antara dua kebudayaan besar tersebut menjadikan sosio-kultural masyarakat Cilacap identik dengan corak masyarakat yang akomodatif dengan perbedaan (primordialisme) (Assidiq 2018). Hal ini karena, masyarakat Cilacap dikenal sebagai masyarakat yang egaliter, terutama masyarakat Cilacap di sebelah barat. Hal ini karena, masyarakat Cilacap di sebelah timur lebih kental dengan corak kultural Kraton Yogyakarta.

Masyarakat egaliter dikenal sebagai masyarakat tanpa kelas (setara). Hal ini, salah satunya dapat dilihat dari keberadaan bahasa yang digunakan masyarakat Cilacap sehari-hari, yakni bahasa ngapak-ngapak (Surahmat 2010). Dalam hal ini, bahasa ngapak-ngapak merupakan bahasa tanpa kelas, berbeda dengan bahasa Jawa pada umumnya yang memiliki kelas bahasa, seperti karma, inggil.

Sifat egalitarianisme masyarakat Cilacap sebagai cara bergaul dimanifestasikan dengan brayan urip (hidup rukun) (Assidiq 2019). Jika dilihat lebih mendalam, brayan urip ikut membangun struktur sosio-politik hubungan antara laki-laki dan perempuan dalam dimensi politik. Dalam hal ini, jika dilihat dari permukaan seolah-olah egalitarianisme menenggelamkan hubungan patriarki dalam cara bergaul masyarakat Cilacap. Egalitarianisme dianggap menjadi satu-satunya faktor determinan, namun kenyataannya dalam konteks politik praktis yang menjadi pembatas hubungan patriarki adalah kekuatan ekonomi.

Dalam konteks hubungan keagamaan, egalitarian menandakan bahwa masyarakat Cilacap tidak begitu terikat dengan hubungan primordialisme keagamaan. Oleh karena itu, corak dominan politik aliran di wilayah ini merepresentasikan abangan.

Abangan sebagai corak utama masyarakat Cilacap juga menandakan bahwa wilayah ini merupakan "kandang banteng." Dengan demikian, parpol penguasa di wilayah ini adalah Partai Demokrasi Indonesia Perjuangan (PDIP). Hal ini dapat diukur dengan kemenangan besar yang diraih PDIP saat penyelenggaraan Pemilu 2019 lalu (Ale 2019).

Meskipun dalam pemilihan bupati (pilbup) pada periode-periode pemilihan akhir-akhir ini yang selalu dimenangkan oleh kandidat yang diusung Partai Golongan Karya (Golkar), namun kemenangan tersebut lebih melihat kepada nama besar kandidat daripada latar belakang parpol. Tatto Suwarto Pamudji yang merupakan bupati petahana dengan keuntungan kepetahanaan (Sukmajati 2015) yang dimiliki dan berkat politisasi birokrasi sebagai bagian dari strategi patronase-klientelisme menjadikan sosoknya menang mutlak dalam pemilihan. Dengan demikian, baik konteks Pemilu 2019 maupun pilbup di Cilacap masing-masing memiliki konteks yang berbeda. Selain itu, dominasi politik PDIP juga dapat dilihat dari perolehan suara sejak tahun 2004, yang mana pada penyelenggaraan Pemilu 2004, PDIP mendapatkan 33,91 persen. Sedangkan Golkar 
pada tahun yang sama hanya memperoleh 20,1 persen suara. Kondisi ini juga bertahan hingga lima tahun sesudahnya, di mana pada Pemilu 2009, PDIP berhasil menjadi partai pemenang dengan memperoleh 27,45 persen. Sedangkan Golkar hanya meraih 14,96 persen.

Pada kenyataannya, jika dilihat secara sosio-ekonomi, maka kemiskinan di Cilacap masih cukup tinggi (Cilacapkab.bps.go.id, n.d.). Demikian halnya dengan tingkat pendidikan masyarakat Cilacap yang masih rendah (Cilacapkab.bps.go.id, n.d.). Kondisi tersebut menjadikan sumber kekuasaan tertinggi adalah adalah kuasa materil. Hal ini karena tingginya ketergantungan masyarakat terhadap keuntungan-keuntungan yang bersifat konkret (materil). Hal tersebut tidak dapat dilepaskan dari kesenjangan ekonomi yang terjadi di Cilacap. Hal ini karena nyatanya ada sebagian elemen masyarakat minoritas etnik yang menguasai ekonomi-politik di Cilacap secara dominan (Assidiq 2018). Dominasi ekonomi-politik mereka pada akhirnya menciptakan distribusi dan alokasi kesejahteraan dirasakan tidak merata (Assidiq 2019), terutama untuk masyarakat Cilacap di bagian barat yang jauh dengan sumber daya.

\section{Kontestasi Politik Perempuan di Cilacap Dalam Diskursus Gender dan Ekonomi Politik}

Penerapan peraturan 30 persen kuota perempuan dalam penyelenggaraan pemilu di Indonesia secara kuantitatif berpengaruh signifikan terhadap kontestasi perempuan dalam panggung politik elektoral. Dalam hal ini, banyak kemudian caleg-caleg perempuan muncul di permukaan mewarnai dinamika politik elektoral di tingkat lokal. Dari sekian banyak caleg perempuan tersebut, beberapa di antaranya memang sudah mempersiapkan diri dengan matang, namun beberapa di antaranya seakan-akan hanya menjadi pelengkap penderita. Kondisi ini tidak dapat terlepas dari realitas pragmatis parpol pengusung yang mengusung sejumlah perempuan hanya untuk kebutuhan memenuhi persyaratan administrasi peserta pemilu.

Bagi sebagian caleg perempuan yang sudah mantap mencalonkan diri, terdapat sejumlah kecil yang berasal dari kalangan masyarakat sipil biasa. Sebagian yang lain berasal dari kalangan masyarakat sipil yang merepresentasikan elit ekonomi-politik. Dalam kenyataannya, jika dilihat dalam konteks penyelenggaraan Pileg 2019 tingkat pusat, maka caleg perempuan yang berhasil memenangkan kursi hanya terdapat tiga orang. Masing-masing di antaranya mewakili kalangan elit ekonomi-politik ditambah karena faktor keuntungan petahana yang mereka miliki. Dua diantaranya adalah caleg perempuan petahana, yakni Siti Mukaromah dari Partai Kebangkitan Bangsa (PKB) dan Novita Wijayanti dari Partai Gerakan Indonesia Raya (Gerindra). Satu di antaranya adalah caleh perempuan pendatang baru, yakni Teti Rohatiningsih, yang merupakan istri Tatto Suwarto Pamudji.

Penerapan sistem calon anggota legislatif (caleg) terpilih adalah yang memperoleh suara terbanyak memungkinkan bagi siapapun untuk memenangkan pemilihan legislatif (pileg). Hal ini mengakibatkan kontestasi antar caleg menjadi sangat kompetitif, baik antara caleg dengan partai politik (parpol) yang sama maupun berbeda. Oleh karena itu, pileg tidak lagi dianggap merepresentasikan pertarungan ideologi antar 
parpol (lemahnya identitas kepartaian) melainkan pertarungan kemampuan personal antar kandidat (candidate-centered politic) (Muhtadi 2013). Perkembangan politik elektoral yang mengarah kepada politik plutokrasi menjadikan kemampuan personal yang paling diperhitungkan adalah modalitas dan aksesibilitas terhadap sumber daya material.

Selain itu, Arah perkembangan politik elektoral Indonesia menuju politik plutokrasi menjadi keuntungan tersendiri bagi caleg petahana (incumbency advantage). Maka tidak heran jika pencalonan kembali caleg petahana menjadi fenomena yang paling sering ditemui dalam pileg di Indonesia. Para caleg petahana ini diuntungkan karena memiliki modal finansial dan aksesibilitas terhadap sumberdaya. Sedangkan penantangnya memiliki margin yang lebar terhadap kedua modal penting itu. Kondisi ini memiliki kecenderungan di mana calon petahana memiliki kesempatan yang sangat besar untuk terpilih kembali.

Jika dilihat dari latar belakang sosio-ekonomi, maka menjadikan materil sebagai modalitas utama sebagai strategi pemenangan menjadi relevan. Kondisi tersebut karena melahirkan hubungan yang cenderung bersifat timpang antara kandidat dan pemilih. Ketimpangan relasi tersebut membangun hubungan yang bersifat dyadic relationship (relasi dua pihak), contingency (relasi yang bersifat dua arah), hierarki, dan pengulangan. Artinya, seseorang dengan kedudukan sosial tinggi (patron) menggunakan pengaruh dan sumber dayanya untuk memberikan perlindungan dan atau keuntungan kepada seseorang yang statusnya lebih rendah (klien).

Kemudian klien membalas pemberian tersebut dengan memberikan dukungan dan bantuan, termasuk pelayanan pribadi kepada patron. Hubungan ini juga memberikan konsekuensi supaya klien yang lemah selalu dituntut untuk setia dalam rangka memperkuat patronnya, dan kesetiaan itu semakin diperlukan pada saat patron dalam situasi tertentu, seperti pemilu. Dengan demikian, atas dasar hubungan ini klientelisme sering digunakan sebagai salah satu bentuk strategi dalam memenangkan pileg. Hal ini, tidak dapat terlepas dari sikap permisif masyarakat Cilacap terhadap politik uang. Sebagai contoh kemenangan fenomenal Teti Rohatiningsih sebagai caleg perempuan pendatang baru dari Partai Golongan Karya (Golkar) pada Pileg 2019 di Cilacap (Dapil VIII Jawa Tengah) diyakini karena modalitas dan aksesibilitas terhadap sumber daya material yang kuat dalam bentuk patronase yang dihubungkan melalui pola dan jaringan yang bersifat klientelistik.

Pola yang dibangun dalam jaringan klientelisme ini menempatkan Teti Rohatiningsih dan suaminya, Tatto Suwarto Pamudji yang notabene merupakan Bupati Cilacap sebagai patron. Tetti Rohatiningsih merupakan Ketua Tim Penggerak Pemberdayaan Kesejahteraan Keluarga (PKK), Bunda PAUD, Bunda Baca, Ketua Dewan Penasihat Gabungan Organisasi Wanita, Ketua Forum Peningkatan Konsumsi Ikan Nasional (Forikan) dan Ketua Gerakan Nasional Orang Tua Asuh (GNOTA) Cilacap menjadikan "emak-emak" sebagai salah satu kekuatan politik utama dalam jaringan klientelismenya. Dalam skala yang lebih besar melalui otoritas yang melekat 
pada suaminya, Teti Rohatiningsih memobilisasi hampir seluruh jajaran birokrat dari tingkat kabupaten hingga desa untuk dijadikan broker dalam jaringan klientelismenya.

Penggunaan patronase dan klientelisme sebagai strategi pemenangan menjadi konsekuensi logis jika melihat Cilacap melalui pendekatan modernis. Hal tersebut karena struktur sosio-ekonomi Cilacap belum modern. Menurut Martin S. Lipset, suatu wilayah dikatakan belum modern diukur dari tingkat kemiskinan dan buta huruf masih relatif tinggi (Lipset 1959). Struktur sosio-ekonomi tersebut secara alami melahirkan struktur sosio-politik di Cilacap yang kental dengan patron-klien. Dalam hal ini, patronklien didefinisikan sebagai suatu relasi dua arah ketika seseorang yang memiliki status sosial ekonomi dan sosial politik yang lebih tinggi (patron) menggunakan pengaruh dan sumber daya yang dimilikinya untuk memberikan perlindungan pada orang lain yang memiliki status sosial ekonomi lebih rendah (klien) yang memberikan dukungan dan bantuan kepada patron. Ketika pileg, jenis dukungan klien terhadap patron yang merupakan caleg adalah pemberian dukungan suara.

Teti Rohatiningsih meraih suara terbanyak di tengah struktur sosio-politik yang patriarkis dan kuatnya dominasi Partai Demokrasi Indonesia Perjuangan (PDIP) serta cengkraman oligarki Franz Lukman di Cilacap. Angka perolehan suaranya mencapai 147.905 suara, jumlah ini mengalahkan perolehan suara Adisatria Suryo Sulistio, caleg PDIP yang menjadi pemenang Pileg 2014, yang mana pada Pileg 2019 meraih 108.428 suara (Afifiyah 2019). Perolehan suaranya tersebut sekaligus mengalahkan perolehan suara Novita Wijayanti, anak Franz Lukman yang merupakan caleg perempuan peraih suara tertinggi pada Pileg 2014 dari Partai Gerakan Indonesia Raya (Gerindra), pada Pileg 2019 meraih 89.074 suara (Afifiyah 2019). Hadirnya Teti Rohatiningsih menurunkan perolehan suara keduanya dengan cukup signifikan.

Selain itu, perolehan suara yang diraih Teti Rohatiningsih juga mengalahkan perolehan suara rekan satu parpolnya, yakni Dito Ganundito. Kemenangan Teti Rohatiningsih atas Dito Ganundito yang merupakan caleg unggulan Golkar karena kebijakan penetapan zonasi yang menutup kemungkinan Dito Ganundito meraup suara di Cilacap. Selain itu, melalui peran suaminya juga melahirkan kebijakan berupa instruksi nonformal kepada kepala desa-kepala desa untuk mempersulit permohonan kampanye bagi caleg lainnya. Menurut penuturan salah satu tim relawan Novita Wijayanti, dirinya mengalami hal tersebut ketika akan melakukan kampanye di tiga desa di Kecamatan Majenang, yaitu Cibeunying, Salebu dan Limbangan.

Menurutnya momen instruksi nonformal ini disampaikan menjelang pemilihan kepala desa (pilkades) serentak. Sehingga apabila para kepala desa tidak mengindahkan instruksi tersebut maka tidak akan diberikan dukungan materil dan nonmaterial saat pencalonannya. Pernyataan ini berdasarkan pada temuan kasus di salah satu desa, yaitu Rejodadi, Kecamatan Cimanggu yang mana calon kepala desa petahana mendapatkan sokongan dana kampanye sebesar 10 juta rupiah yang berasal dari Teti Rohatiningsih. 


\section{Kesimpulan}

Tujuan dari penulisan makalah ini adalah untuk membuka realita kualitatif penerapan kuota 30 persen perempuan dalam penyelenggaraan politik elektoral di tengah-tengah gelombang besar oligarki di Indonesia. Pada kenyataannya, meskipun secara kuantitatif kuota 30 persen perempuan dapat dikatakan mengarah kepada kondisi yang ideal, namun secara kualitatif kontestasi perempuan sangat dipengaruhi oleh modalitas ekonomi atau representasi mereka sebagai kalangan elite ekonomi-politik. Hal ini menjadi logis ketika kita menyaksikan bersama bahwa penyelenggaraan perkembangan pemilu di Indonesia yang kian mahal hanya untuk memenangkan kursi parlemen.

Dengan demikian, modalitas ekonomi menjadi satu-satunya faktor determinan dalam kontestasi perempuan dalam politik elektoral di Indonesia, dalam hal ini di Cilacap sebagai salah satu representasi wilayah di Indonesia. Meskipun, Cilacap secara sosio-kultural dan sosio-politik cenderung tidak berpihak kepada Tetti Rohatiningsih, namun karena kondisi status quo sebagai istri Bupati Cilacap, menjadikannya dengan mudah memenangkan Pileg 2019. Hal ini berkat aksesibilitas terhadap kekuasaan untuk dapat dengan mudah mengadakan hal-hal yang berhubungan dengan pengadaan patronase dan klientelisme sebagai satu-satunya strategi pemenangan paling signifikan. 


\section{BIBLIOGRAFI}

Afifiyah, Siti. 2019. “Tommy Kurniawan Dan 540 Anggota DPR RI Terpilih.” 14 Mei 2019. 2019.

Ale. 2019. "PDIP Raih Suara Tertinggi Di Cilacap." 9 Mei 2019. 2019. https://satelitpost.com/regional/cilacap/pdip-raih-suara-tertinggi-di-cilacap.

Assidiq, Fajar. 2018. "Komunitas Arab Dan Penyebaran Salafisme Analisis Ekonomi Politik Peran Keluarga Bawazier Di Kota Cilacap." Universitas Jenderal Soedirman.

Assidiq, Fajar. 2019. "Menguatnya Perkembangan Salafisme Dan Dominasi Ekonomi Kelompok Bisnis Arab Di Banyumas.” Integralistik.

Cilacapkab.bps.go.id. n.d. "Persentase Penduduk Miskin Kabupaten Se-Eks Karesidenan Banyumas."

Fitriyah. 2015. "POLITIKA, Vol. 6, No.2, Oktober 2015 . 101” 6 (2): 101-11. Google Scholar

Idrus, Muhammad. 2007. Metode Penelitian Ilmu-Ilmu Sosial. Yogyakarta: UII Press. Google Scholar

Lipset, Martin Seymour. 1959. "Some Social Requisites of Democracy: Economic Development and Political Legitimacy.” American Political Science Reviw, 69105. Google Scholar

Marwah, Sofa. 2014. Kontestasi Perempuan \& Politik Dalam Budaya Banyumas. Cetakan Pe. Purwokerto: Universitas Jenderal Soedirman. Google Scholar

Muhtadi, Burhanuddin. 2013. "Politik Uang Dan Dinamika Elektoral Di Indonesia: Sebuah Kajian Awal Interaksi Antara Party-Id Dan Patron-Klien." Jurnal $\begin{array}{lllll}\text { Penelitian } & \text { Politik } & 10 & (1): & 369 .\end{array}$ http://ejournal.politik.lipi.go.id/index.php/jpp/article/view/217. Google Scholar

Muhtadi, Burhanudin. 2018. "Buying Votes in Indonesia," no. February. Google Scholar

Rofieq, Ainur, and Rahmat Nuryono. 2017. "Pengaruh Klientilisme Terhadap Perilaku Pemilih Masyarakat Kecamatan Sukatani Pada Pilkada Kabupaten Bekasi 2012." Politik Indonesia: Indonesian Political Science Review 1 (2): 105. https://doi.org/10.15294/jpi.v1i2.6577. Google Scholar

Stokes, Susan C., Thad Dunning, Marcelo Nazareno, and Valeria Brusco. 2014. Brokers, Voters, and Clientelism. Brokers, Voters, and Clientelism. https://doi.org/10.1017/cbo9781107324909. Google Scholar 
Fajar Assidiq, Krisnaldo Triguswinri

Sukmajati, Edward Aspinall \& Mada. 2015. Politik Uang Di Indonesia: Patronase Dan Klientelisme Pada Pemilu Legislatif 2014. Cetakan I. Yogyakarta: Penerbit PolGov. Google Scholar

Surahmat. 2010. "Cablaka Sepanjang Hayat,” 2010.

First publication right:

Jurnal Syntax Fusion: Jurnal Nasional Indonesia

This article is licensed under:

(ㅇ) (1) ( $)$ 